\title{
Education Process Using Learning Videos for Students in SD Katolik 15 St. Laurentius Manado
}

\author{
Lianly Rompis ${ }^{1 *}$ \\ ${ }^{1}$ Electrical Engineering Study Program, Faculty of Engineering \\ Universitas Katolik De La Salle Manado, Indonesia \\ lrompis@unikadelasalle.ac.id \\ Julie Rante ${ }^{2}$, Ryan Singgeta ${ }^{3}$, Alexander Patras ${ }^{4}$, Kristian Dame $^{5}$, Verna Bokau ${ }^{6}$, \\ Chrysantus Padachan ${ }^{7}$, Victori Polly ${ }^{8}$ \\ 2,3,4,5,6,7,8 Electrical Engineering Study Program, Faculty of Engineering, \\ Universitas Katolik De La Salle Manado, Indonesia \\ jrante@unikadelasalle.ac.id,rsinggeta@unikadelasalle.ac.id, apatras@unikadelasalle.ac.id, \\ kdame@unikadelasalle.ac.id, vbokau@unikadelasalle.ac.id, cpadachan@unikadelasalle.ac.id, \\ vpolly@unikadelasalle.ac.id
}

(Received April 08, 2021, accepted May 03, 2021)

\begin{abstract}
This community service activity is a form of dedication from Lecturers of Electrical Engineering Study Program in Universitas Katolik De La Salle Manado to apply the sciences and skills in helping Indonesia that currently is facing a global problem which is related to the appearance of Covid-19 virus. It is of course gives impact in education system that indirectly forcing people to do an online learning and all the lecturers have to work from home. This matter encouraged us as lecturers in Electrical Engineering Study Program Universitas Katolik De La Salle Manado to help maintaining the education process of students in SD Katolik 15 St. Laurentius Manado so they can study well and gain knowledge from home through online learning. What we actually did was together with our Electrical Engineering students created a simple learning material in the form of video. The main topic for our material is related to electricity. As a result, we designed and created three learning videos for the students and we hope that these will help the students to briefly understand the basic concept of electricity and how to make a simple electric circuit. We are also hoping that this activity will help the parents economically to support the education of their children. The outcome of this community service activity are videos and report.
\end{abstract}

Keywords: community service; electricity; elementary school; learning video 


\section{Introduction}

Nowadays our country Indonesia is arriving at the New Normal Era of facing the Covid-19 virus pandemic. The education process in elementary schools have already started but still prioritize the health and clean so the students can be avoided from Covid-19 virus that would be dangerous for their own health and family. Generally all schools still conduct online learning using the information technology media and internet network.

To support Information Technology literacy for children and also the use of digital content for science and technology, Electrical Engineering Study Program Universitas Katolik De La Salle Manado (Unika De La Salle Manado) conducts a community service program that considered essential to be established during this New Normal and also a kind of new approach for online education process (Liliana, 2010) (Handarini \& Wulandari, 2020).

From the result of our oral survey to some parents of elementary school students in SD Katolik 15 St. Laurentius whom lives in the area of Paal II Ranomuut Manado, we got conclusion that the learning process of their children were not or could not fully conducted in the form of online learning because of financial support and lack of facilities to support the purpose of online learning. Besides, there are also some other specific considerations that made the children can only gained materials from their teachers through social media such as Whatsapp application (WA) and did the homeworks from home independently. For students that had limitation in using WA, they would be given time to finish and submit the tasks at school, including following the mid term and final term test.

Based on this background, lecturers in Electrical Engineering Study Program Unika De La Salle Manado were called to serve the students so they can follow the education process during the pandemic and get support from a simple learning material made by Electrical Engineering lecturers and students (Rahajeng, Maretasani, \& Kristanto, 2018)

The main topic of the learning material is electricity, consists of 3 (three) sub-topics/videos: the benefits and hazards of electricity, the making of LED card, and series-parallel cirucits. 


\section{Methods}

The methods we used for this community service activity contains of several procedures, i.e. conduct oral survey and observation, choose proper topic and sub-topics, design concept for video material, prepare the components and devices, create the learning videos, and implement the online learning using IT technology such as YouTube and Zoom Applications (Sangadji \& Sopiah, 2010) (Raco \& Tanod, 2012).

The data and results for the community activities were acquired from interviews and observation reports during our visit to the school and giving online learning (Rahajeng, Maretasani, \& Kristanto, 2018) (Leylasari, Cahyadi, \& Wicaksono, 2018) (Yustisiana \& Meilasari, 2018).

This community service was organized in a team of Electrical Engineering lecturers and students from October 2020 until March 2021. This activity is planning to keep on going in the future, can be conducted by educators who have special attention on elementary school students' education. The concept and technology of the learning material concept could always be improved to support the government educational programs and education of millennial. Although probably in the future this community service activity does not being conducted or re-programmed routinely, but at every turn and time could be considered as positive alternative for lecturers and students to extend their scientific insight and improve their soft skills and hard skills.

\section{Results and Discussions}

\section{Results}

The community service activity was conducted in SD Katolik 15 St. Laurentius Manado and was aimed to educate the $1^{\text {st }}$ grade to $3^{\text {rd }}$ grade elementary school students with learning videos. The total number of students in this school is 54 (1st grade has 21 students, $2^{\text {nd }}$ grade has 10 students and $3^{\text {rd }}$ grade has 23 students).

There were 4 (four) main programs in our activity: gave stationary as a Christmas gift, made a video about the benefits and hazards of electricity, made a video about making a LED card, and made a tutorial video about assembling simple series-parallel circuits. 
Out team contacted the school principle, Mrs. Telda Ticoalu and sent an official letter. After being approved, we started our first program on December $4^{\text {th }} 2020$ by giving stationary for each student of $1^{\text {st }}$ grade to $3^{\text {rd }}$ grade as shown in Figure 1 and Figure 2.
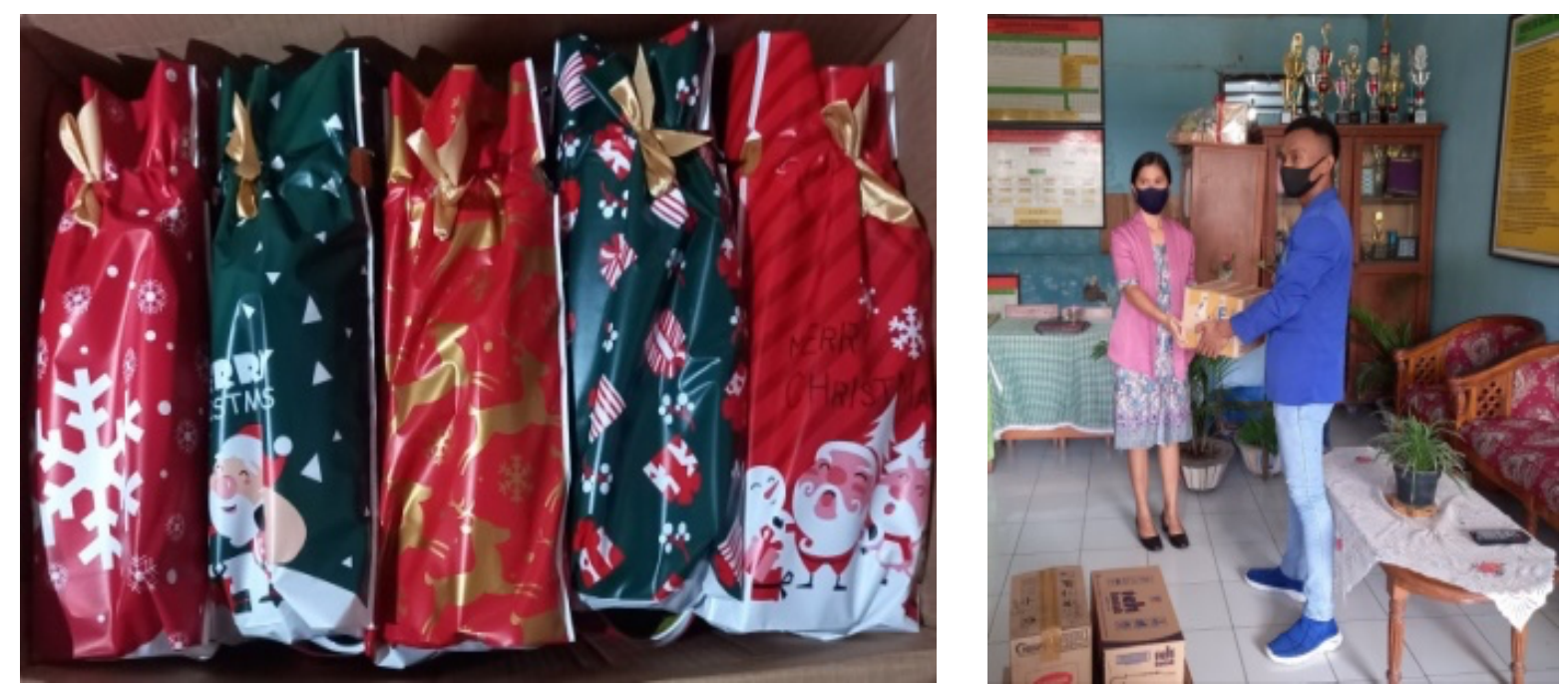

Fig. 1. Stationary as a Christmas gift for the school and students

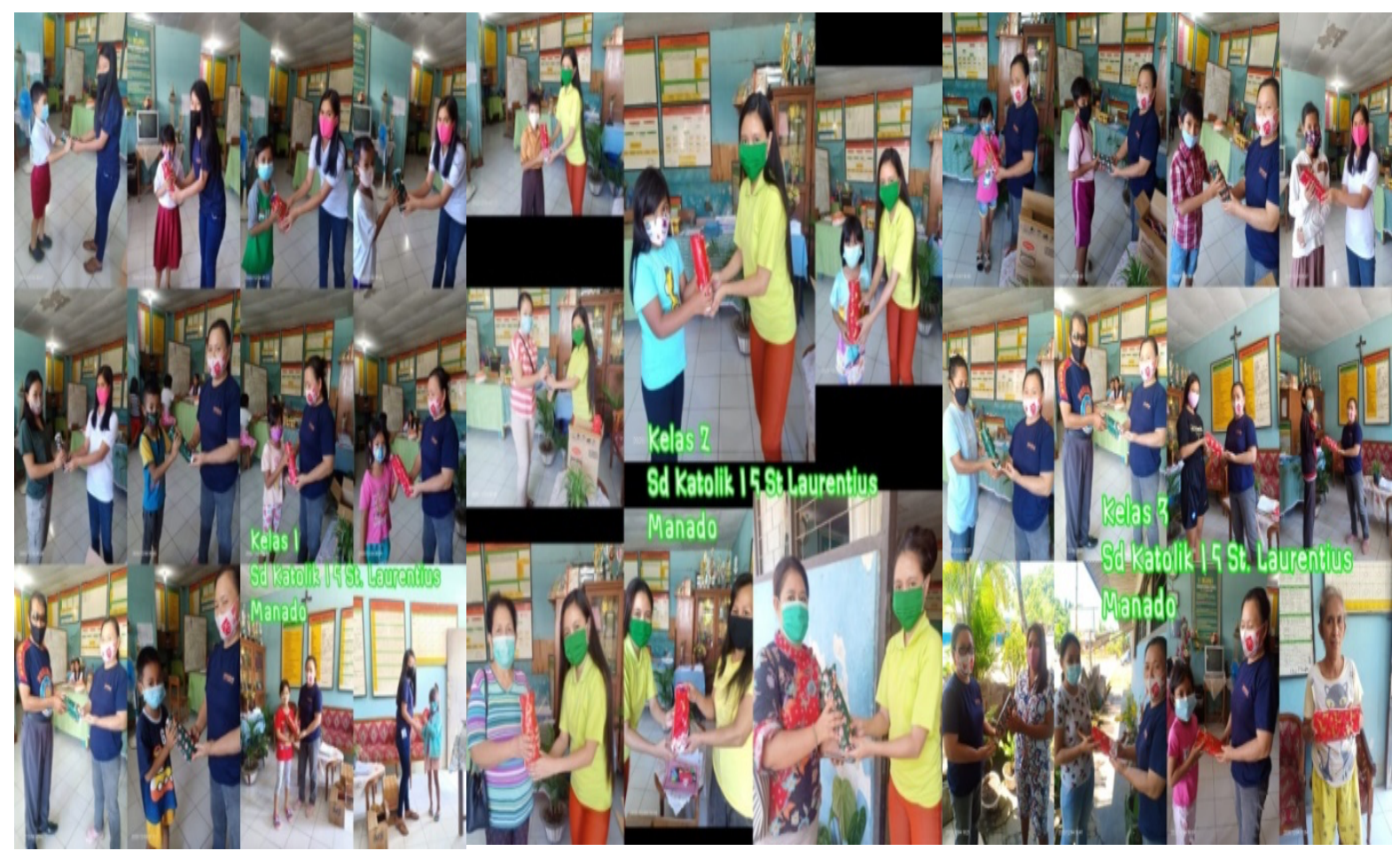

Fig. 2. Students and parents came to school and received the Christmas gift

The second program was a learning video about the benefits and hazards of electricity, as shown in Figure 3. This learning video was made with the help of our university students for selecting pictures and the idea of animations, and then uploaded to YouTube. On January $20^{\text {th }}$ 
2021, our team gave online presentation to those elementary school children with Zoom application, as shown in Figure 4.

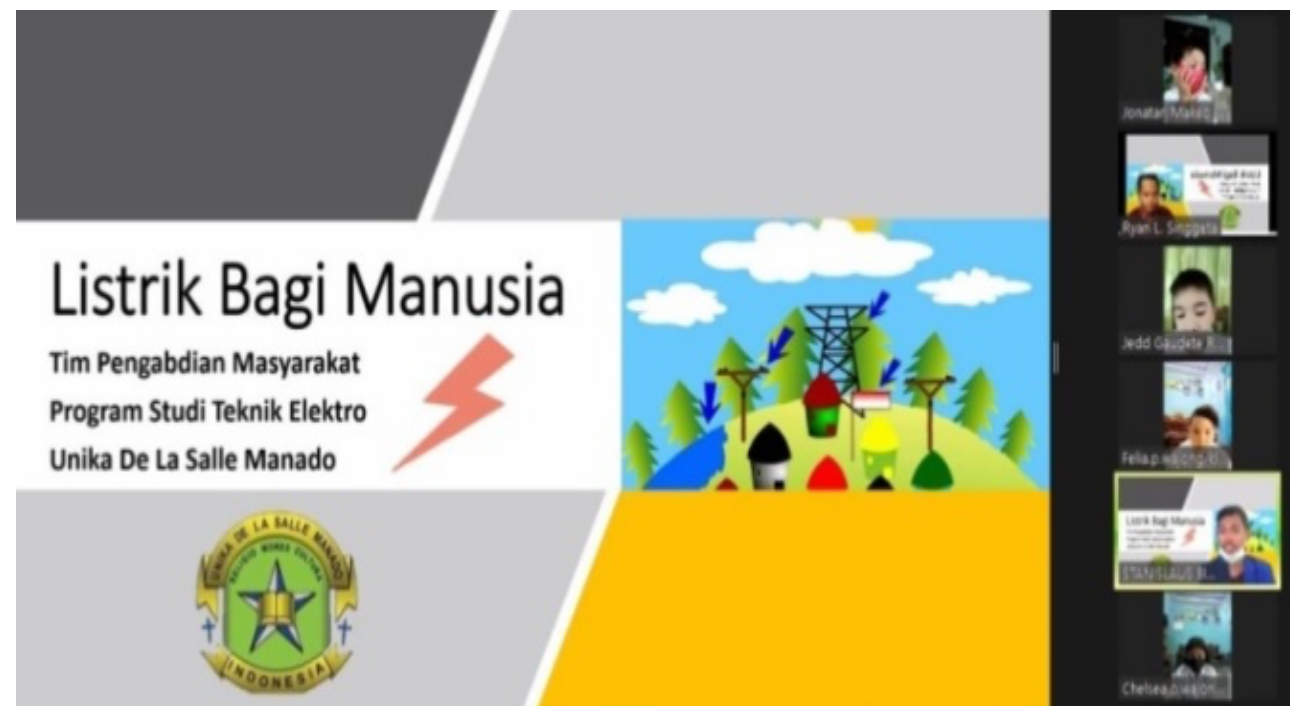

Fig. 3. A learning video about the benefits and hazards of electricity

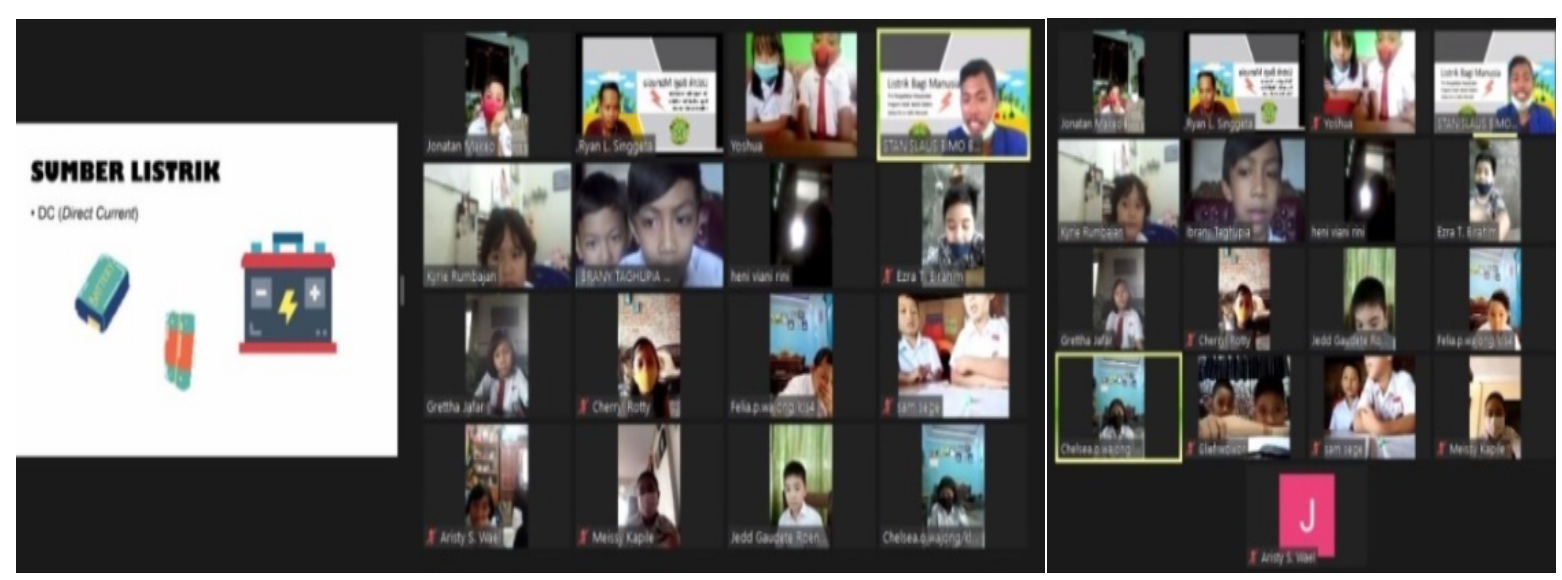

Fig. 4. Online presentation using Zoom application (electricity and LED card)

The third program was a tutorial video of how to make a Christmas card or Easter card using LED, Resistor and Battery as shown in Figure 5 and Figure 6. The children were given instructions to make the LED card (Figure 7) and also the video link to watch it. Our university students helped making the video and uploaded on YouTube. On January $20^{\text {th }} 2021$, our team gave online presentation with Zoom application, as shown in Figure 4. 


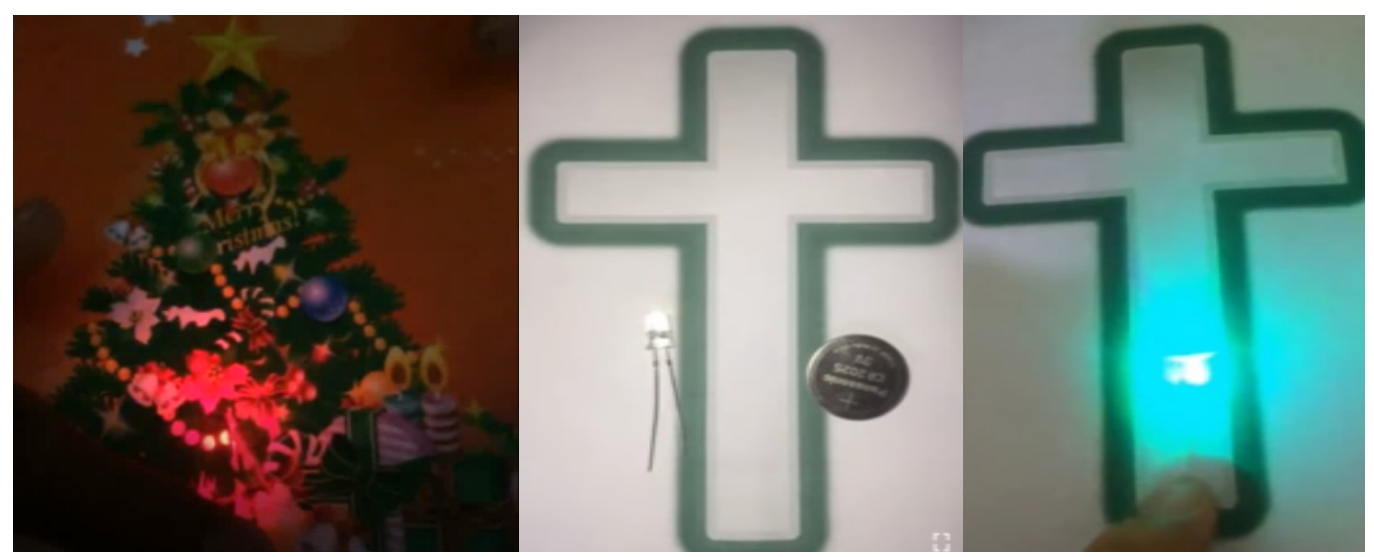

Fig. 5. A LED card for Christmas and Easter

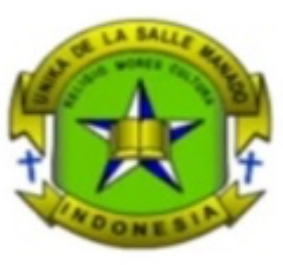

DAVID REGAR

19011002

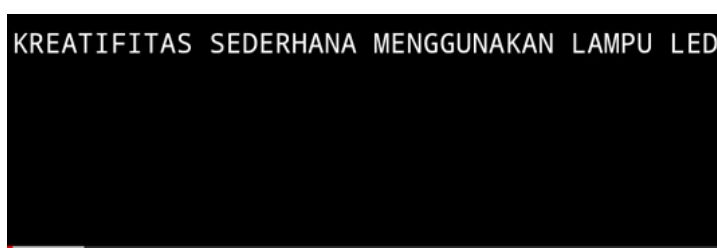

KREATIFITAS SEDERHANA MENGGUNAKAN LAMPU LED

$\Leftrightarrow 22 \times$ ditonton 1 minggu lalu

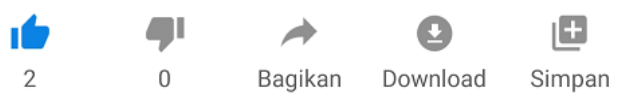

KREATIFITAS SEDERHANA MENGGUNAKAN LED

Fig. 6. Tutorial video about making a LED card

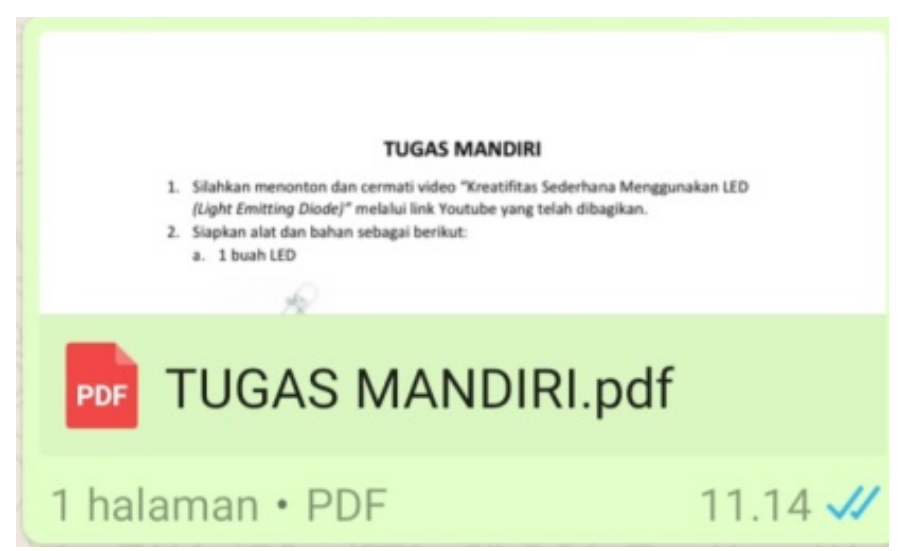

Fig. 7. Instruction for children to make LED card of their own

The fourth program was series-parallel video. Our university student involved in this activity and helped us upload the video in Google Drive. On March $26^{\text {th }} 2021$, our team gave online presentation with Zoom application. These activities are all shown in Figure 8 and Figure 9. 
Tutorial Merangkai

\section{Rangkaian Seri \& Paralel}

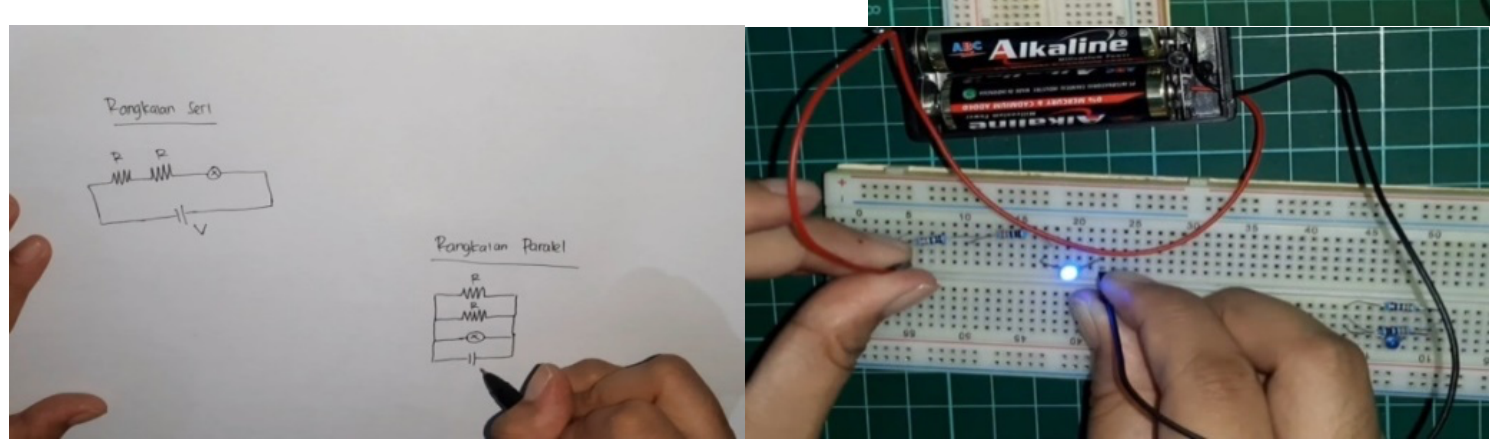

Fig. 8. Series-parallel circuits tutorial video

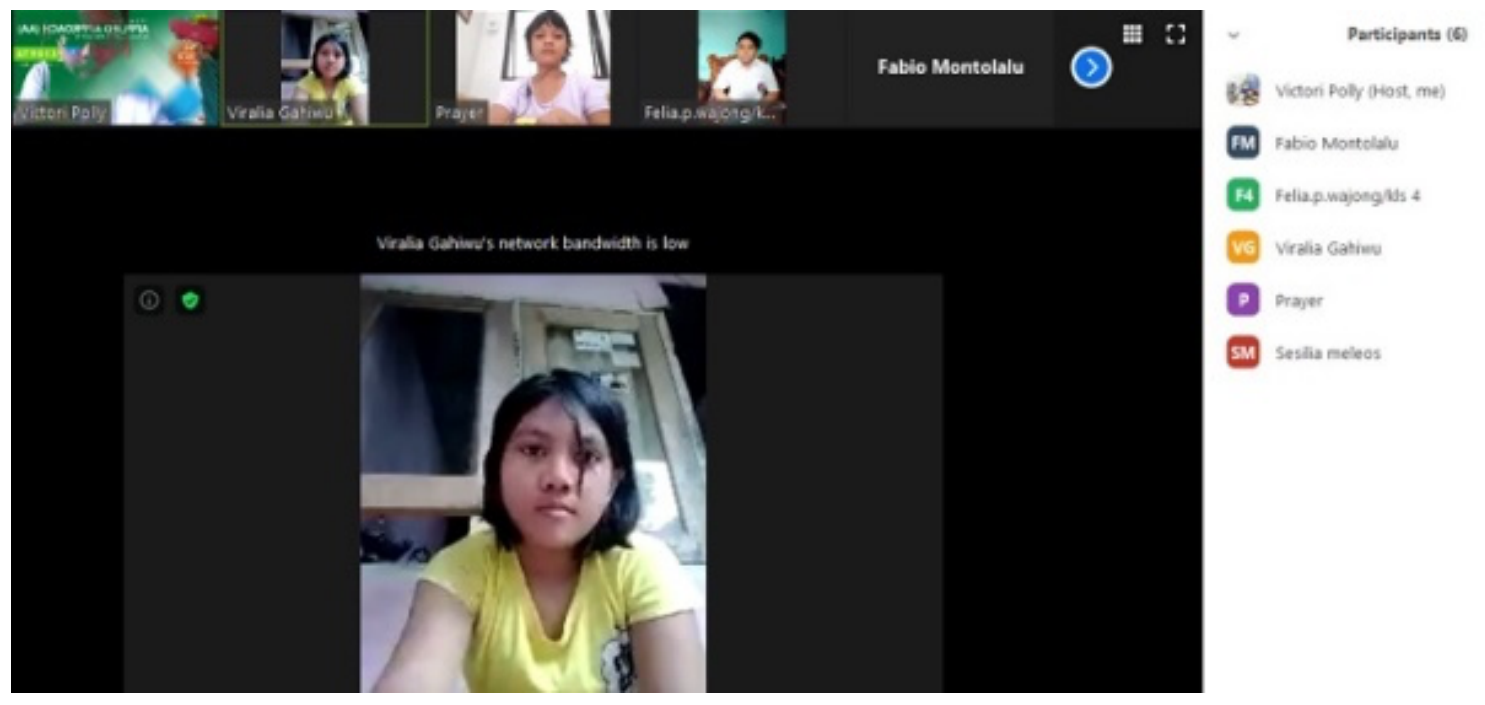

Fig. 9. Online presentation using Zoom application (series-parallel circuits)

Our dedication through those activities got positive responses from the school, children and parents. We are welcome to conduct other good activities in the next semester to support teachers and also the children. All the learning videos were published online on YouTube and can be accessed by those children anytime. Children would get to know better about Electricity, LED card and Simple Electric Circuit for improving their knowledge and creativities.

From our team's observations and surveys and also comments obtained from the School's Principal and few Parents, those children did understand and could explain the topics well enough during the online Zoom meeting, and practiced the result with LED card assessment. 
Those children gave positive enthusiastic during online and also participated in online quizzes. The results are detail described in Table 1.

Table 1. Results and feedbacks from community service activities

\begin{tabular}{cll}
\hline No & Respondent & \multicolumn{1}{c}{$\begin{array}{c}\text { Comment/ } \\
\text { What was Observed }\end{array}$} \\
\hline 1 & Principal & $\begin{array}{l}\text { a. This was a good program during Covid-19 pandemic } \\
\text { b. Children looked enthusiastic } \\
\text { c. Children got more familiar with Zoom }\end{array}$ \\
& Parent & $\begin{array}{l}\text { a. Felt happy for the support } \\
\text { b. Children could access valuable knowledge } \\
\text { a. Learn new technology of online learning } \\
\text { b. Develop creativities in learning }\end{array}$ \\
\hline
\end{tabular}

\section{Conclusion}

The community service activity being conducted by Electrical Engineering lecturers and students was found to be very useful for elementary school students in SD Katolik 15 St. Laurentius Manado in order to broaden their knowledge about electricity, LED card and series-parallel circuit. The other important benefit was to improve the hardskill and softskill of Electrical Engineering lecturers and students in learning the subject of Basic of Electrical Engineering and Electric Circuit. They can understand and learn more about the subject and can practically implement what they had learned. The concept and technology of the learning material concept could always be improved to support the government educational programs and education of millennial.

\section{Acknowledgements}

We thanks our students Stanislaus Bundu and Barten Sandung for their contributions in selecting pictures, giving ideas in making the animations for the learning videos, and teaching the children. Also David Regar and Aurelia Tampi for helping designing the LED cards and making the series-parallel electric circuits video.

\section{References}

Liliana. (2010). Knowledge Management and Social Learning. Seminar Nasional Riset dan Teknologi Terapan (pp. 234-247). Jakarta: Universitas Katolik Atma Jaya.

ISBN: 978-602-97094-0-7 
Handarini, O. I., \& Wulandari, S. S. (2020). Pembelajaran Daring sebagai Upaya Study From Home (SFH) Selama Pandemik Covid 19. Jurnal Pendidikan Administrasi Perkantoran (JPAP), 8(3), 496-503.

Sangadji, M., \& Sopiah. (2010). Metodologi Penelitian-Pendekatan Praktis dalam Penelitian. Yogyakarta: Penerbit ANDI.

Raco, J. R., \& Tanod, R. R. (2012). Metode Fenomenologi: Aplikasi pada Enterpreneurship. Jakarta: PT Grasindo.

Rahajeng, R., Maretasani, L. D., \& Kristanto, V. H. (2018). Meningkatkan Ketrampilan Menghitung dengan Media Pembelajaran Ultah Camp dan Puzzel Geometri pada Anak Sekolah Dasar. Jurnal Warta Abdimas Media Sosialisasi Hasil Kegiatan Pengabdian Masyarakat Universitas Katolik Widya Mandala Madiun, 1(1).

http://adl.aptik.or.id/default.aspx?tabID=61\&id=169302\&src=a

Leylasari, H. T., Cahyadi, A., \& Wicaksono, D. (2018). Pendampingan Psikologis bagi Siswa Kelas VI SDK Santo Bernardus Madiun. Jurnal Warta Abdimas Media Sosialisasi Hasil Kegiatan Pengabdian Masyarakat Universitas Katolik Widya Mandala Madiun, $1(1)$.

http://adl.aptik.or.id/default.aspx?tabID=61\&id=169304\&src=a

Yustisiana, A., \& Meilasari, P. (2018). Bahasa Inggris Pintar di SDN 02 Mojorejo Madiun. Jurnal Warta Abdimas Media Sosialisasi Hasil Kegiatan Pengabdian Masyarakat Universitas Katolik Widya Mandala Madiun, 1(1).

http://adl.aptik.or.id/default.aspx?tabID=61\&id=169304\&src=a 